\title{
THE OTHER SIDE OF THE "ISTRIAN EXODUS": IMMIGRATION AND SOCIAL RESTORATION IN SLOVENIAN COASTAL TOWNS IN THE 1950s
}

\author{
Aleksej KALC
}

COBISS 1.01

\section{ABSTRACT \\ The Other Side of the "Istrian Exodus": Immigration and Social Restoration in Slo- venian Coastal Towns in the 1950s}

The article addresses the migration processes in the fifteen years after WWII in what is today's Slovenian coastal region. The main emphasis is on the immigration following the annexation of this area to socialist Yugoslavia in 1954. The replacement of the population, the radical change of the ethnic structure and the geography of the immigration inflow are outlined. Some questions that affected the immigration and repopulation process are discussed and some possibilities for further research are presented, i.e. the policy and management of the migration processes, the inclusion patterns of the newcomers and the relationships among the indigenous and immigrant components.

KEY WORDS: Slovenian coastal region, Istrian exodus, immigration, population replacement, ethnic change

\section{IZVLEČEK}

Druga plat »istrskega eksodusa«: Priseljevanje in družbena obnova v slovenskih obalnih mestih v petdesetih letih 20. stoletja

Prispevek obravnava migracijske procese na slovenskem obalnem območju v obdobju petnajstih let po drugi svetovni vojni. Poudarek je na priseljevanju, ki je sledilo priključitvi območja socialistični Jugoslaviji leta 1954. Prikazane so zamenjave prebivalstva, etnične spremembe in geografski izvor priseljenskih tokov. Nakazani so tudi nekateri problemi, ki so vplivali na priseljevanje in nastajanje nove družbene stvarnosti. Med vprašanji, vrednimi raziskovanja, avtor poudarja politiko in upravljanje priseljenskega procesa, oblike vključevanja prišlekov v novo okolje ter odnose med priseljenci in lokalnim prebivalstvom.

KLJUČNE BESEDE: slovenska obala, istrski eksodus, priseljevanje, zamenjava prebivalstva, etnične spremembe

PhD in History, Slovenian Migration Institute ZRC SAZU, Novi trg 2, SI-1000 Ljubljana; AKalc@ zrc-sazu.si - The article is a result of the projects "Social, economic and cultural history of Slovenian emigration (1945-1991)" (J5-8246) and "Migration control in the Slovenian area from the times of Austria-Hungary to independent Slovenia" (J6-8250) and the research programme "National and Cultural Identity of Slovenian Emigration in the Context of Migration Studies" (P5-0070). All are financed by the Slovenian Research Agency. 


\section{THE ISSUE}

In the fifteen years after the Second World War, the towns of Koper, Izola and Piran on what is now the Slovenian coast underwent the replacement of the majority of their populations. This led to radical changes in their social, ethno-linguistic and cultural fabrics. The ethnic structure of the entire coastal area was also transformed, with the presence of the ethnic Italian component being greatly reduced. The change was related to the post-war border issue between Italy and Yugoslavia, and the incorporation of Istria into the Federal People's Republic of Yugoslavia. It triggered the mass emigration of the Italian population from Istria and all those who objected to Yugoslav sovereignty in the territory, those who did not see a future in the new socialist social order, and those whose traditional and vital economic connections with Trieste had become compromised.

As elsewhere in Istria, this emigration process from Koper, Izola and Piran, which entered the Italian historical memory as the "exodus", took place from the end of the war onward, when these towns were first part of the Julian March (Venezia Giulia / Julijska krajina) and then from 1947 part of the Free Territory of Trieste (FTT), more precisely its Zone B, which was administered by the Yugoslav army. However, it reached its climax with the abolition of the FTT as an independent state under the Anglo-American and the Yugoslav military administrations and the partition of Zones A and B between Italy and Yugoslavia in accordance with the 1954 London Memorandum. The emigration from the former Zone B of the FTT was the last stage of the "exodus" from Istria and the territories that had formed part of Italy during the period between the two wars. The population that emigrated from Zone B was approximately $70 \%$ Italian, while the remaining emigrants were mostly Slovene. ${ }^{1}$ Since the Italian population in Istria was concentrated in the urban areas, this process was particularly disruptive for Koper, Izola and Piran, as well as other coastal towns. This resulted in a demographic gap and social change that was reflected in the economy, in the occupational structure of the population, and in the general functioning and further development of the traditional role of the towns in this region.

But most importantly, the emigration process interrupted the historical continuity in this inhabited area, which lost the product of centuries of ethnic, anthropological, cultural and everyday life. These spaces became available to new arrivals who were

1 The application of national or ethnic categories in multiethnic areas is of course questionable and often misleading, since the ethnic or national identity of people in many cases cannot be clearly defined. This is especially true for Istria, considering its multiethnic and multilingual social fabric, as well as not only the cohabitation but also the mixing of ethnicities and cultures. On the other hand, the nation-building processes and the various related interests and conflicts had a major influence on people when declaring their national identity, and on the authorities when classifying or labelling people arbitrarily according to national categories. This has to be borne in mind with regard to references to the national/ethnic categories in this paper. For a first approach to the question of identities as a basic and controversial issue in historical research in Istria see for example Panjek (2006: 9-14), D'Alessio (2006) and Ballinger (2006). 
already coming from Slovenia and the whole of Yugoslavia to settle there in search of opportunities for a new life. It was not just a matter of replacing the former population in the sense of taking over job vacancies and occupying the empty homes and properties left behind by the emigrants. What occurred was in fact the repopulation of the area and the construction of a new social reality. On the one hand, this reality became integrated into the existing urban settlements which continued to exist, in changed circumstances, in their ancient living environments, historical heritage and the remnants of the former social community. On the other hand, the newly-formed social reality created by immigrants from regions near and far reshaped and in all respects gave new meaning to the old inhabited area, and led to the development of new suburbs with their own linguistic and ethnic, social, economic and cultural-anthropological features.

All of this took place as part of the systematic implementation of the socialist order and its institutional structures. A less explicit ideological version of this system had already been established by the Yugoslav military administration at the time of the Free Territory of Trieste. It became fully operational after 1954, when the region was fully integrated into the Yugoslav state. This phase also coincided with the Slovenian republican government's comprehensive policy of reorganization and development of the economic structure of the coastal area. This was intended not only to support the development of the area itself, but also because of the strategic importance it gained for the republic's interests as Slovenia's sovereign access to the sea.

The issue of population changes in the Slovenian coastal area and in Istria as a whole has been at the centre of attention in international historiography for decades. However, the focus has almost exclusively been on only part of this complex process - the emigration and the history of the Istrian diaspora in Italy and elsewhere. The "Istrian exodus" has received attention as a traumatic example of exile and ideologically induced migration. As a product of the Second World War and the dispute regarding the national borders in the northeastern Adriatic, in which the world's superpowers were involved, the exodus has been explored from numerous points of view. The extensive bibliography referring to this topic includes studies on its quantitative dimensions and demographic characteristics (e.g. Colella 1958; Colummi et al. 1980; Fornasin, Zacchigna 2007; Gombač 2005a, b), the causes, motives and political implications of the process (Ballinger 2002; Pupo 2005), the refugees' lives and the impact on the resettlement areas in Italy and other receiving countries (e.g. Pupo 2005; Volk 2004), the reorganization patterns and identity maintenance of Istrian emigrants' communities, and last but not least, on Istrians of Italian descent who decided to remain and are still living in Istria as part of the officially recognised national minority (e.g. Nemec 1998, 2012).

The great impact of the emigration overshadowed the process of the demographic and social restoration of the area affected by the exodus, rendering it a less conspicuous phenomenon. Despite the fact that the restoration and remodelling of the society was a fundamental historical aspect and a factor in the post-war 
development of the Slovenian coastal region, it was almost completely ignored in historiographic and other research. In the 1990s, the same historians in Slovenia, after decades of tabooization, focused their research on the exodus (Gombač 2000, 2001, 2005a, 2005b; Volk 1999, 2004; Troha 2000a, 2000b). This was due to the increasing international academic debate on the population displacements in 20th century Europe, and especially the central place that the forced or politically induced migrations in the North Adriatic area had in the confrontation between Italian and Slovenian historiographers, whose governments had demanded that they shed light on the history of Italian-Slovenian interstate relations and contribute to their normalisation (Slovensko-italijanski 2001).

Some authors only touched upon the issue of the social restoration in Istria in a handful of studies or references in the field of demography (Titl 1961; Pletikosić 2000, 2001; Josipović 2006). In the historiographic debate about the region and its postwar history, it is merely referred to as a less important topic in the framework of the history of institutions, political and economic events and culture. It is also omitted from the most recent syntheses that offer a comprehensive overview of migration movements and their resulting changes in the ethnic composition of the population in the area spanning $20^{\text {th }}$ century Slovenia, Italy and Croatia (Purini 2010; Catalan et al. 2007). It has never been formulated as a separate historical issue worthy of its own specific conceptualisation, complete with an analysis and interpretation of its systemic and other aspects. However, there has been an increase in the number of sociological and anthropological studies on the relationships between the indigenous and immigrant populations which contribute to the linguistic structure as well as the social differentiation and identification of the space (Sedmak 2002, 2004; Hrobat Virloget et al. 2015, Virloget 2015).

The topics of immigration and the social restoration of Slovenian coastal towns are issues that are closely intertwined with other events that changed the structure of the Slovenian coastal region in the decades after the Second World War. They must be approached from different points of view - from demographic, economic and political to sociological, anthropological and cultural. They must be read through a complex explanatory analysis and through consideration of the issue in its multifaceted forms at a local level and as a matter involving central Slovenian and Yugoslav interests and political plans. In view of the current state of the research, this article of course cannot aspire to develop such an ambitious discussion. It intends to address only some aspects of the issue and offer an insight into the demographic process, with a focus on its dimensions, dynamics and geographical extensions. The outline is based on censuses, data taken from the few studies referring to the topic, and data deriving from migration statistics kept by the administrative units in the context of registering the population and supplying data to the central Statistical Office of the Republic of Slovenia (Titl 1961; Pletikosić 2000, 2001). Some organizational aspects and specific circumstances regarding the process of immigration and the inclusion of the new population in the local social context are also outlined. 


\section{A Look at the Numbers: The "Exodus"}

The area of observation is the territory of the former Zone B of the Free Territory of Trieste, which was transitioned into the state framework of Yugoslavia in 1954 and annexed to the People's Republic of Slovenia. In 1945 this area had a total of 46,350 inhabitants, 18,500 of whom lived in the towns of Izola, Koper and Piran, and the rest in villages in the rural hinterland. Over the next few years, the population saw a slight increase, but then started to decline in 1949 and dropped to 42,000 in 1956. The population then started to rise rapidly and the 1961 census for the area shows nearly 50,000 inhabitants. This fluctuation reflected the wave of mass emigration of the population into Zone A of the Free Territory of Trieste and then into Italy, and of the immigration of a new population coming from the Slovenian and the wider Yugoslav area.

The year 1956 marked a turning point in the demographic development of the area due to the fact that the exodus had for the most part finished, and the population reached its lowest point since the $1880 \mathrm{~s}$. At that point, the area was given an entirely new identity. This is most strongly reflected in the fact that, compared to 1945 , the presence of the Italians had declined by $92 \%$, and that the average age of the remaining Italian national community had increased significantly (Titl 1961: 19). Since the Italian population was concentrated in cities with a traditionally Roman character, and since the rural areas were characterised by the Slovenian element, the demographic developments are most clearly reflected in the towns of Izola, Koper and Piran. As shown in Table 1, the populations of all three towns were on the rise after 1945 and then fell on average by almost a quarter from 1948 to 1956. Even more illustrative is the ethnic metamorphosis of the old urban settlements (Table 2). While Italians accounted for over 91\% of the population in 1945, by 1956 their share had dropped to just over $10 \%$. Koper and Izola were most affected by this change, but the percentage of the Italian community in Piran was only slightly higher. A similarly drastic decline in the Italian component was also recorded in rural areas where Italians had also been present, and in certain places had accounted for the majority of the population.

Table 1: Populations of the towns of Izola, Koper and Piran from 1945 to 1956

\begin{tabular}{|c|c|c|c|c|c|}
\hline & 1945 & 1948 & 1956 & $\begin{array}{c}\% \text { of } 1945 \\
\text { pop. }\end{array}$ \\
\hline Izola & & 7,272 & 7,941 & 6,008 & 75.7 \\
\hline Koper & & 6,138 & 6,859 & 6,066 & 88.4 \\
\hline Piran & & 5,035 & 5,350 & 3,574 & 66.8 \\
\hline Total & & 18,445 & 20,150 & 15,648 & 77.7 \\
\hline
\end{tabular}


Table 2: Italian population of the towns of Izola, Koper and Piran (\%)

\begin{tabular}{|c|c|c|c|c|}
\hline & & 1945 & & 1956 \\
\hline Izola & & 95.0 & & 9.0 \\
\hline Koper & & 87.4 & & 8.3 \\
\hline Piran & & 91.3 & & 15.8 \\
\hline Total & & 91.5 & & 10.3 \\
\hline
\end{tabular}

Sources: Cadastre national (1945); Prijava prebivalstva (1951); Stalno prebivalstvo (1956)

The emigration of Italians as well as other ethnic groups began immediately after the war; however, many politically exposed persons had already left the area during the war, before the Yugoslav military forces took control of the region in May 1945. The reasons and motivations for this emigration, which was directed mainly to Trieste, were of a political and national, but also a social and economic nature. The phenomenon was also contributed to by the establishment of a "people's government" and by the gradual introduction of the socialist social order, as well as, of course, the policy of the Yugoslav authorities against "enemies of the people" and "class enemies", to which the Italian population was particularly vulnerable since most of its members belonged to the bourgeois class. In addition to arrests, epuration trials, deportations and initially also liquidations, the push factors also included "property enforcement measures" (confiscation of property) and various forms of dispossession. One such measure was the elimination of the colonato leasing system and the allocation of land and the associated inventory to the farmers who cultivated it, which led to the departure of major rural landowners (Bonin 2004; Rogoznica 2011).

Other objective and subjective motivations affecting this emigration included the area's traditional ties and economic attachment to Trieste, which had always represented both a source of labour and an agricultural market. Trieste remained the centre of gravity and employment and was even further strengthened in this role during the time of the Free Territory of Trieste. Many people had jobs in and close family or other ties to Trieste, and thus decided to move out of the Yugoslav military administered Zone B and into the Anglo-American administered Zone A. The process was accelerated in the early 1950s when it became clear that the days of the FTT were numbered and that the Trieste issue would be resolved by dividing its territory between Yugoslavia and Italy (Colummi 1980). The civil authorities under the Yugoslav military administration in Zone B who were charged with managing the economy also began to adapt more rapidly to the social and political system in accordance with the principles of communist ideology and society during this time (Rogoznica 2011). According to registry offices, over 14,000 people (Titl 1961: 17; 1965: 126) emigrated from the Slovenian coastal region in the period from the end of the war to the concluding of the London Memorandum in October 1954, which led to the elimination of the FTT and the demarcation of the border between 
Italy and Yugoslavia. A large share of the departures in the period from 1945 to 1950 were of an illegal nature (Gombač 2005a). This population outflow acquired the dimensions of a mass emigration after the issuing of the bilateral note of October 1953, through which the administration of Zone A of the Free Territory of Trieste was allocated to the Italian civil authorities (just before this, in September, Tito had announced the annexation of Zone B to Yugoslavia as soon as Italy entered the territory of Zone A).

The emigration reached its peak a year and a half after the annexation of Zone $B$ to Yugoslavia. The London Memorandum enabled the people of both zones of the FTT to opt for either Yugoslav or Italian citizenship and emigrate accordingly (Gombač 2005a; Lavrenčič 2012). As a result, in 1955 more than 8,000 people opting for Italian nationality left the Slovenian coastal region and a further 2,200 left during the following year and up to the end of February 1957, when the time limit for emigration expired (Lavrenčič 2012). From the end of the war and until the beginning of 1957 , nearly 24,400 people emigrated from the Slovenian coastal region in the exodus, accounting for almost 53 percent of the population of the territory recorded by the 1945 census (Titl 1961).

In addition to the aforementioned pressures and in many cases a hostile environment, this phenomenon was contributed to by the political propaganda of the Italian side, warning against the alleged danger to ethnic Italians under the Yugoslav regime, and their subsequent invitation to people to leave the area and come into the embrace of their Italian homeland. This emigration wave had settled by May 1956. Of those opting for the Italian side, about 29 percent were Slovenes and a slightly lower proportion were Croats (Gombač 2005a). Unlike the Italians, who had been emigrating over the entire period, the majority of Slovenes left between November 1955 and April 1956, which coincides with the authorities' attempts to discourage the emigration of Slovenes and Croats (Gombač 2001).

\section{A Look at the Numbers: Immigration}

The process of immigration, on the other hand, also started immediately after the war - in the spring of 1945 - and took place in stages coinciding with and trailing the fluctuations of the "exodus". Up until 1948, when emigration had not yet begun, immigration contributed to a slight population growth that would compensate for the population decline in the coming years. Numerically it was fairly limited, as by 1954 the population registry offices had recorded only 2,600 cases of permanent internal immigration to the area of the Slovenian coastal region. However, significant migratory movements were also taking place within the region itself during this period, with people moving from rural areas of the hinterland to the coast and to the outskirts of towns. Due to these movements (and not only due to emigration to Trieste, which was at this stage restricted mainly to family members of farming 
families, and had not affected small peasant landowners), the majority of the villages in the hinterland began losing their population, while the population was increasing in certain coastal and suburban areas. For example, the villages of Korte and Pomjan lost one quarter and one fifth of their inhabitants respectively from 1946 to 1954.

On the other hand, the population increased by $20 \%$ in the immediate vicinity of Piran, by $33 \%$ in Semedela (a suburban area of Koper) and by $15 \%$ in the territory surrounding the town of Izola. The population also increased in the area of Portorož and in the hilly area along the border with Zone A of the FTT. The migration to this border zone was related to employment opportunities in Trieste and in particular those in the maritime and industrial town of Milje (Muggia) on the south coast of the Gulf of Trieste. Milje (in Zone A) was the gravitational centre of this border part of Zone B, and up to 1945 had also been part of the same local administrative unit (Titl 1961: 20-21).

In its early years, the influx of immigration into the Slovenian coastal region was connected mainly with the establishment of the new socialist governmental and administrative structures, as well as with employment in public and military administration, and political and social institutions. Two examples of this are the Slovenian education and cultural sectors, which were newly established after the war, after twenty years of prohibition under fascism in the context of programmes aimed at assimilating the Slovenian and Croatian populations and during the period of the Italianisation of the eastern province of Julian March acquired after WWI. The opening of Slovenian primary and secondary schools (which also offered teacher training programmes), two grammar schools, a technical school, a commercial-maritime school, a music school and a school of viticulture and fruit growing attracted numerous teaching staff to the coastal region.

These professionals had previously not been present in this area. For this reason, schools and departments had been shrunk and combined, and teaching had been left to teaching staff who had not yet completed their studies (Peterle Grahonja 2004; Beltram 1989: 113-114). Similarly, there was also an influx of personnel to be employed at cultural institutions such as administrative units, theatres, sports facilities, libraries and other institutions, e.g., banks, public health services (these were newly established on the basis of compulsory health insurance, while earlier the population had relied on the health services of the Trieste hospital for care (Rogoznica 2004; Stergar, Rupel 1998). Immigration also comprised managerial and technical staff who worked in start-up companies and other skilled personnel with specialized training as engineers, architects and several kinds of technicians. This was all the more evident from the early 1950s onward, which saw the beginning of the mass emigration of the Italian educated classes. Immigration was particularly apparent in the field of economics and in technical occupations and managerial positions at production facilities and firms established within the framework of programmes intended to revive the economy and reduce the region's dependence on Trieste. 
The waves of mass departures in 1953 and especially between 1954 and 1956 accelerated the migration movements from the hinterland into the towns and between the municipalities of the Slovenian coastal region. What was particularly evident was an increased influx of the population coming in from external regions. The registration offices recorded a total of almost 12,500 new residents in the years of 1955 and 1956, when the exodus reached its peak and then tailed off. Immigration thus exceeded the number of departures by 21 percent. In the following three years, another 7,000 people immigrated to this region at a fading pace - 3,449 in 1957; 2,306 in 1958; and 1,522 in 1959. From 1955 onward, the area acquired nearly 20,000 new residents. Immigration and the positive rate of natural increase contributed to turn the demographics in a positive direction for the first time since the First World War.

Table 3: Emigration in the context of the "exodus" and immigration to the Slovenian coastal region from 1945 to 1960

\begin{tabular}{|c|c|c|c|c|}
\hline \multirow{2}{*}{ Period } & \multicolumn{2}{|c|}{ Emigration } & \multicolumn{2}{c|}{ Immigration } \\
\hline & $\mathrm{N}$ & $\%$ & $\mathrm{~N}$ & $\%$ \\
\hline $1945-1954$ & 14,115 & 57.9 & 2,594 & 11.6 \\
\hline $1955-1956$ & 10,274 & 42.1 & 12,421 & 55.7 \\
\hline $1957-1959$ & & & 7,277 & 32.6 \\
\hline Total & 24,389 & 100 & 22,292 & 100 \\
\hline
\end{tabular}

Source: Data taken from Titl (1961)

The case of the town of Piran, investigated by Ivica Pletikosić, offers a closer look into the dynamics of the events. There was a phase of a positive migration movement in the early post-war years. In 1950, a negative trend begins with an intense emigration into Zone A of the Free Territory of Trieste. During this period and until 1952 there is then a slight decrease in the influx of new population, after which it begins to rise gradually corresponding to each major emigration wave, namely the one in the winter of 1953, the one from the spring to the autumn of 1954, and the last one from the spring to the autumn of 1955 . The influx of immigrants rises significantly from October 1954 onwards and remains stable until the end of 1957, after which it slightly fades over the next three years. Despite its strength, this influx fails to compensate for the losses caused by the exodus with its large scale and fast pace until the end of 1955. This leads to a reduction in the population of Piran to around 3,000 in January of 1956. From then on, the population begins to rise again to reach a total of 3,574 inhabitants in the census of April 1956 and as many as 5,474 inhabitants in 1961. The inclusion of the area into the Yugoslav state framework in 1954 thus marked a turning point in the course of immigration and in the replacement of the population. 
Immediately after and also during the mass emigration from the town, others were immigrating into the town and managed to fill the demographic gap in only a few years. A similar trend was occurring throughout the territory of the municipality of Piran (Table 4), while the same dynamics can also be observed in the municipalities of Koper and Izola (Pletikosić 2000; 2001).

Table 4: Immigrant population of the municipality of Piran by year of immigration in the 1961 census

\begin{tabular}{|c|c|c|}
\hline Year & No. of immigrants & $\%$ \\
\hline $1946-1947$ & 97 & 1.3 \\
\hline $1948-1952$ & 683 & 8.9 \\
\hline $1953-1955$ & 2,494 & 32.5 \\
\hline $1956-1957$ & 2,048 & 26.7 \\
\hline $1958-1959$ & 1,348 & 17.6 \\
\hline $1960-1961^{*}$ & 1,006 & 13.1 \\
\hline Total & 7,676 & 100 \\
\hline
\end{tabular}

*up to 31 March 1961

Source: Pletikosić $(2000,2001)$

The effects of population replacement, which in such a short time changed the face of the Slovenian coastal region and in particular its towns, were as follows: in 1948, $85 \%$ of the population was born in this region, while the rest were immigrants from the Federal People's Republic of Yugoslavia (6.7\%), Trieste and the Croatian part of Zone B of the Free Territory of Trieste (6.2\%) and other countries (Prijava prebivalstva 1951). In April 1960, according to the registry offices, the number of natives fell to $49 \%$; in the rural areas this percentage decreased to $65 \%$ and to $33 \%$ in urban areas. Immigrants from the FPR Yugoslavia accounted for $46 \%$ of the population, while the percentage of immigrants from Trieste declined to $2.8 \%$, with the rest coming in from other countries (Titl 1961). Thus, over this short period of time a profound ethnic change in terms of "Yugoslavization", and especially "Slovenization", occurred in this territory.

\section{Where Were They From?}

Where were the immigration flows directed from and how did the phase transitions affect their geographical origin? As noted above, the migrations during the time of the FTT predominantly took place within the Slovenian coastal region, with immigrants coming in from Zone A and from Yugoslavia. These immigrations were largely associated with employment in the military and civil administration, and also in the 
newly established social and economic structures. Many immigrants were political refugees from Trieste and pre-war Venezia Giulia who emigrated to Yugoslavia in the 1920 s and 1930s fleeing fascist persecution. After the war, many returned and found employment in various pro-Yugoslav organizations and political and economic structures in Zone A of the FTT under the direction of the parallel Slovene "people's" government. As there was a shortage of all kinds of Slovenian personnel in Zone B, many people moved there. Some also immigrated from Zone A for political or ideological reasons or due to issues with the American military administration. These kinds of people were particularly valuable in both zones (but highly undesirable in anti-Yugoslav circles and to the Anglo-American military government in Zone A) as they were highly motivated and committed to the ideals of the National Liberation Movement and the new Yugoslavia. Above all, they possessed detailed knowledge of the situation and the specifics of the entire territory of the FTT.

After the integration of Zone B into the Yugoslav framework, the geographic nature of immigration flows changed. After the immigration from the former Zone A of the FTT of those who had opted for the Yugoslav side, this flow declined considerably. On the other hand, the source pool of immigration expanded to include Slovenia and part of Croatia. In the context of Slovenia, two western regions stood out. One is the immediate coastal hinterland: the municipalities of Hrpelje, Sežana, Ilirska Bistrica and Postojna. In 1960, 7.2\% of the inhabitants of the Slovenian coastal region were born in this belt. The second region was Gorizia, which was the region of origin for $8 \%$ of the population (Titl 1961: 31). These two regions shared a historical affinity with the Slovenian Littoral, having belonged to a common administrative framework which dated back to Austrian times and later joined the province of the Julian March under Fascist Italy. With the peace treaty and demarcation between Italy and Yugoslavia in 1947, the Gorizia region was cut off from its historical regional centre of Gorica, which had been annexed by Italy. This led, on the Slovenian side, to the building of the entirely new urban settlement of Nova Gorica, which became the administrative and economic centre of the region. It was home to the population of the Gorizia region and other Slovenian areas. After 1954, a large percentage of the population of Gorizia region began seeking opportunities in the newly acquired Slovenian coastal towns.

The influx of a new population to the Slovenian coastal region was drawn from the entire territory of the People's Republic of Slovenia (19.5\%). The largest flows originated in the administrative areas of Ljubljana, Maribor and Celje (in north-western Slovenia), Novo Mesto (southern Slovenia) and Murska Sobota (on the border with Hungary) (ibid.: 32). As for the rest of the Yugoslav territory, the Slovenian coast became particularly attractive to migrants from neighbouring Croatia, into which the natural hinterland of northern Istrian coastal towns reaches. In 1945, fewer than 100 inhabitants of Croatian ethnicity lived in the Slovenian coastal region, while at the end of 1956, a total of 2,800 inhabitants originated from Croatia; in 1960 their number was over 5,000 , i.e. $11.7 \%$ of the population. Many came in from the neighbouring 
district of Buzet, the wider Istrian peninsula and the Croatian coastal belt. Many of these immigrants would form specific occupational segments which replaced the emigrated population, particularly in fisheries and food processing, while many also found employment in shipping, and others settled in the rural areas (ibid.: 31).

The accelerated immigration following the London Memorandum coincided with the policy of the planned development and comprehensive integration of the region into the context of the Slovenian Republic, which had now passed into the hands of the Slovenian central government (during the time of the FTT, it had been under the auspices of local political actors). Although international law in the FTT did not allow for Yugoslav interference, the Communist Party surreptitiously introduced the socialist economic and social concept into Zone B. It also strove to raise the region's economic prospects and to reduce the economic dependence of Zone B on Trieste. After the annexation of the region, the development policy was put into full effect and the area began to develop in line with the new regional urban and economic plans (Kralj Pavlovec 1997). The Slovenian territory of the region gained a new economic position and prospects. The priorities of the socio-economic development plan included the promotion of industrialisation, the maritime industry and tourism.

Plans of national importance began to be implemented, such as the construction of the Port of Koper, industrial plants such as the moped manufacturer Tomos, Delamaris, a food processing corporation which merged former producers of tinned fish, Splošna Plovba International Shipping and Chartering, and several other food, metal and other factories. Construction and trade companies were established, the existing tourism facilities were renovated and several new ones were built. Considerable effort went into the development of agriculture, fishing and salt panning (Rogoznica 2011). The main area of economic development and a functional role of the region was spatial planning and organising new urban layouts (Čebron Lipovec 2012 , 2018). The influx of the population and the emergence of a new social fabric was an integral part of these processes, which called for a labour force of all types and qualifications and which created opportunities for the integration of the new population into the region.

The process of immigration into the individual parts of the coastal region proceeded at different paces, which were conditioned by employment and settlement opportunities. The exodus had caused a general labour deficit and depleted the occupational structure (Gombač 2006). All of a sudden, several occupational sectors vanished, for example the crafts sector, as craftsmen retreated across the borders en masse due to the collectivisation process. Izola's tinned fish producers lost $90 \%$ of their workforce (Gombač 2006: 283; Kramar 2003: 196). Several villages lost a vast majority of their inhabitants (Kramar 2003: 196). This all left a mark on production rates, which dropped to the lowest levels in all economic sectors in 1956. Immigration gradually and unevenly filled the demographic gap and workforce needs. 
Immigration also faced many obstacles, and it was barely able to keep up with the demand for human resources. Issues occurred especially in the mobilisation of highly-educated experts, as there was a deficit in all sectors. One of the reasons behind this was housing. The Municipality of Koper had a quarter of its work posts vacant at the end of 1955 because of housing. The medical centre had only one fulltime doctor, who lived in a hotel in Koper. The centre could not find or keep additional full-time staff due to the poor housing situation, as doctors tended to leave after a short time. For the same reasons, crafts and trade companies could not find management and accounting personnel. In schools, $60 \%$ of the positions were filled by new teachers with no experience who lived in rural areas in especially poor conditions. Housing issues affected work flow and led to the turnover of specialist staff at large industrial plants. The housing commission therefore favoured immigrants when allocating flats, which was a cause of tension.

New blocks of flats were only beginning to be built, and a large percentage of flats that belonged to optants were in need of renovation. Optants often left their houses to relatives or other trusted administrators, so the housing commission could not freely dispose of them and assign them to applicants. Many newcomers didn't like these flats due to the low standards (including a lack of sewage and sanitation), and many were not happy to live in them (Zapisniki sej skupščine občine Koper 1955-1957). In the early years, the old town centres became merely transition points for many migrants. An ever-changing stream of people passed through them before their population stabilized. Unlike the exodus, this immigration was not unidirectional. Many newcomers only came temporarily and then left, mainly moving around the territory before settling down. These few examples give the idea of the circumstances in which the inflow of newcomers was taking place as well as of the issues the political and administrative bodies had to face in managing the economic revitalization and social renewal of the area.

\section{SUGGESTIONS FOR FURTHER RESEARCH}

The repopulation and social renewal process of the Slovenian coastal area affords numerous possibilities and issues for further research. I will present just a few. The first is the political authorities' attitude towards the issues and towards organisation and process management. To what extent was the process left to its own devices, and to what extent was it regulated? What political, management and economic factors affected in it and in what ways? What were the criteria for the mobilisation of human resources for the needs of the coastal region? A second series of questions relates to immigration strategies deployed by immigrant newcomers and their adaptation to the new living environment. The third level of issues concerns the integration of migrants into the new social environment from the point of view of interpersonal relationships among the immigrants themselves and between them 
and the locals, and their involvement in the shaping of a newly emerging social and cultural amalgam. In this regard, a specific issue is raised by the relationship between the new population and the Italian community as the repository of the Venetian and Italian historical and cultural heritage.

The issue of the cohabitation of the "old" people and the "new" people coming in from Slovenia was even broader and quite controversial. It emerged at the political level with conflicts between the local and central political authorities. The central communist leadership considered the locals still rooted in the mentality of the Free Territory of Trieste and conditioned by that political experience. As a consequence, the region would have difficulty implementing the socialist order in conformity with the official political programmes. Divergences in character and views emerging in everyday social relationships were for example the sentiment of opposition towards the so-called "Carniolans" - managerial staff from central Slovenia in the administrative and economic sectors and other organizations. The years considered in this paper constituted only the first and most intensive phase of the remodelling of the area's social fabric. The process continued throughout the 1960s and 1970s, with an increase in immigration in the form of labourers from Southern Yugoslav republics, which met the rising demand for labour. This influx brought about a further redefinition of the social and ethnic structure, with implications in cultural relations and in daily life.

\section{REFERENCES}

Ballinger, Pamela (2003). History in Exile. Memory and Identity at the Borders of the Balkans. Princeton, N.J., Woodstock: Princeton University Press.

Ballinger, Pamela (2006). Opting for Identity: The Politics of International Refugee Relief in Venezia Giulia, 1948-1952. Acta Histriae 1, 115-140.

Beltram, Vlasta (1989). Povojni razvoj slovenske Istre - Koprski okraj 1945-1947. Kronika: Časopis za slovensko krajevno zgodovino 37, 108-116.

Bonin, Zdenka (2004). Življenje v Coni B Tržaškega svobodnega ozemlja. Cona B tržaškega svobodnega ozemlja: Zbornik ob 50-letnici priključitve cone B STO Jugoslaviji. Koper: Pokrajinski arhiv, 9-58.

Catalan, Tullia et al. (2007). Dopoguerra di confine - Povojni čas ob meji. Trieste: Università di Trieste, Dipartimento di Scienze Geografiche e Storiche; Regione autonoma Friuli Venezia Giulia.

Colella, Amedeo (1958). L'esodo dalle terre adriatiche: Rilevazioni statistiche. Rim: Opera per l'assistenza ai profughi giuliani e dalmati.

Colummi, Cristiana, Ferrari, Liliana, Nassisi, Gianna, Trani, Germano (1980). Storia di un esodo: Istria 1945-1956. Trst: Istituto regionale per la storia del movimento di liberazione nel Friuli Venezia Giulia. 
Čebron Lipovec, Neža (2012). Arhitekturni pomniki izgradnje Kopra po drugi svetovni vojni. Annales: Series Historia et Sociologia 1, 211-232.

Čebron Lipovec, Neža (2018). Izgradnja slovenskih obalnih mest v času po drugi svetovni vojni: Primer mesta Koper. Doktorska disertacija. Koper: Univerza na Primorskem, Fakulteta za humanistične študije.

D'Alessio, Vanni (2006). Istrians, Identifications and the Habsburg Legacy: Perspectives on identities in Istria. Acta Histriae 1, 15-39.

Fornasin, Alessio, Zacchigna, Marianna (2007). L'esodo dal Capodistriano nel secondo dopoguerra: Nuove indagini quantitative. Dopoguerra di confine - Povojni čas ob meji (ed. Tullia Catalan et al.). Trieste: Istituto regionale per la storia del movimento di liberazione nel Friuli Venezia Giulia; Università di Trieste; Regione autonoma Friuli Venezia Giulia, 575-588.

Gombač, Jure (2000). Izseljevanje iz Kopra in okolice v letih 1954-1956 - L'esodo da Capodistria e dal suo circondario negli anni 1954-1956. Annales: Series Historia et Sociologia 2, 411-418.

Gombač, Jure (2001). Izseljevanje iz Kopra in njegove okolice po sprejetju Londonskega memoranduma: Analiza podatkov odhajajočih skozi prizmo narodnosti. Annales: Series Historia et Sociologia, 2: 295-402.

Gombač, Jure (2005a). Esuli ali optanti?: Zgodovinski primer v luči sodobne teorije. Ljubljana: Založba ZRC.

Gombač, Jure (2005b). Izseljevanje iz Slovenskega dela Istre po letu 1955 v luči izseljenskih seznamov in izselitvenih dovolilnic jugoslovanskih oblasti. Vojna in mir na Primorskem: Od kapitulacije Italije leta 1943 do Londonskega memoranduma leta 1954 (ur. Jože Pirjevec, Gorazd Bajc, Borut Klabjan). Koper: Knjižnica Annales, 295-306.

Hrobat Virloget, Katja, Gouseff, Catherine, Corni, Gustavo (eds.) (2015). At Home but Foreigners: Population Transfers in 20th century Istria. Koper: Annales University Press.

Hrobat Virloget, Katja (2015). Breme preteklosti: Spomini na sobivanje in migracije v slovenski Istri po drugi svetovni vojni. Acta Histriae 3, 531-554.

Josipovič, Damir (2006). Učinki priseljevanja v Slovenijo po drugi svetovni vojni. Ljubljana: Založba ZRC.

Kralj Pavlovec, Jasna (1997). Regionalni načrt slovenske obale (1959). Zbornik Primorske - 50 let. Koper: Primorske novice, 20-24.

Kramar, Janez (2002). Izola 1945-1991: Iz zgodovine občine od osvoboditve izpod fašizma do ustanovitve samostojne Republike Slovenije 25. junija 1991. Koper: Zgodovinsko društvo za južno Primorsko.

Lavrenčič, Leo (2012). Demografska slika italijanske manjšine v Kopru po poteku roka za izselitev leta 1956. Acta Histriae 3, 505-532.

Nemec, Gloria (1998). Un paese perfetto. Storia e memoria di una comunità in esilio: Grisignana d'Istria (1930-1960). Trst: Istituto regionale per la cultura istriana; Gorizia: Libreria editrice goriziana. 
Nemec, Gloria (2012). Nascita di una minoranza. Istria 1947-1965: Storia e memoria degli italiani rimasti nell'area istro-quarnerina. Fiume: Unione italiana; Trieste: Università popolare; Università degli studi, Dipartimento studi umanistici; Rovigno: Centro di ricerche storiche.

Panjek, Aleksander (2006). Ricostruire trieste: Politiche e pratiche migratorie nel secondo dopoguerra. Trieste: EUT.

Peterle Grahonja, Verica (2004). Slovensko šolstvo Julijske krajine in STO 1945-1954: Tržaško okrožje in koprski okraj. Cona B tržaškega svobodnega ozemlja:Zbornik ob 50-letnici priključitve cone B STO Jugoslaviji. Koper: Pokrajinski arhiv, 85-106.

Pletikosić, Ivica (2000). Migracije v Piranu med drugo svetovno vojno in neposredno po njej. Annales: Series Historia et Sociologia 1, 217-230.

Pletkosić, Ivica (2006). Rudnik Sečovlje: Pregled migracijskih gibanj (1950-1970). Acta Histriae 2, 299-311.

Pupo, Raoul (2005). Il lungo esodo. Istria: Le persecuzioni, le foibe, I'esilio. Milano: Rizzoli.

Purini, Piero (2010). Metamorfosi etniche: I cambiamenti di popolazione a Trieste, Gorizia, Fiume e in Istria 1914-1975. Udine: Kappa Vu.

Rogoznica, Deborah (2004). Posebnosti zdravstvene organizacije in sistema zdravstvenega zavarovanja na območju slovenskega dela Cone B STO. Cona B tržaškega svobodnega ozemlja: Zbornik ob 50-letnici priključitve cone B STO Jugoslaviji. Koper: Pokrajinski arhiv, 109-125.

Rogoznica, Deborah (2011). Iz kapitalizma v socializem: Gospodarstvo cone B Svobodnega tržaškega ozemlja 1947-1954. Koper: Pokrajinski arhiv.

Sedmak, Mateja (2004). Dinamika medetničnih odnosov v slovenski Istri: Avtohtoni versus priseljeni. Annales: Series Historia et Sociologia 2, 291-302.

Sedmak, Mateja (2002). Kri in kultura: Etnično mešane zakonske zveze v Slovenski Istri. Koper: Zgodovinsko društvo za južno Primorsko, Znanstveno-raziskovalno središče Republike Slovenije.

Slovensko-italijanski odnosi 1880-1956 / I raporti italo-sloveni 1880-1956 / Slovene-Italian relations 1880-1956 (2001). Poročilo slovensko-italijanske zgodovinsko-kulturne komisije / Relazione della commissione storico-culturale italo-slovena / Report of the Slovene-Italian historical and cultural commission. Koper/Capodistria: Inštitut za novejšo zgodovino.

Stergar, Miloš, Rupel, Aldo (1998). Množična in športna gimnastika. Fizkulturna organiziranost na Primorskem 1945-1953. Gorica.

Titl, Julij (1961). Populacijske spremembe v Koprskem primorju: Koprski okraj bivše cone B. Tipkopis. Koper: Osrednja knjižnica S. Vilhar.

Titl, Julij (1965). Socialnogeografski problemi na koprskem podeželju. Koper: Lipa.

Troha, Nevenka (1997). STO - Svobodno tržaško ozemlje (1947-1954). Zbornik Primorske - 50 let. Koper: Primorske novice, 56-59.

Troha, Nevenka (2000a). Ukrepi jugoslovanskih oblasti v Conah B Julijske krajine in Svobodnega tržaškega ozemlja in Italijani na Koprskem. Annales: Series Historia et Sociologia 1, 203-216. 
Troha, Nevenka (2000b). Preselitve v Julijski krajini po drugi svetovni vojni. Prispevki za novejšo zgodovino 1, 255-268.

Volk, Sandi (1999). Ezulski skrbniki: Vloga in pomen begunskih organizacij ter urejanje vprašanja istrskih beguncev $v$ Italiji v luči begunskega časopisja 1945-1963. Koper: Zgodovinsko društvo za južno Primorsko.

Volk, Sandi (2004). Esuli a Trieste: Bonifica nazionale e rafforzamento dell'italianità sul confine orientale. Udine: Kappa Vu.

\section{STATISTICAL AND ARCHIVAL SOURCES}

Cadastre national de l'Istrie: d'après le recensement du 1er octobre 1945 (1946). Sušak: Edition de l'Institut Adriatique.

Prijava prebivalstva za preskrbo v Istrskem okrožju z dne 15. 12. 1948 (1951). Ljubljana: Statistični urad Slovenije.

Stalno prebivalstvo v občinah Izola, Koper in Piran 25. 4. 1956 (1957). Ljubljana: Zavod za statistiko.

Zapisniki sej skupščine občine Koper (1955-1957). Pokrajinski arhiv Koper / Regional archive of Koper: Občinski ljudski odbor občine Koper. 


\section{POVZETEK}

\section{DRUGA PLAT »ISTRSKEGA EKSODUSA«: PRISELJEVANJE IN DRUŽBENA OBNOVA V SLOVENSKIH OBALNIH MESTIH V PETDESETIH LETIH 20. STOLETJA \\ Aleksej KALC}

Avtor v članku obravnava migracijske procese na območju slovenskih obalnih mest $\checkmark$ petnajstih letih po drugi svetovni vojni, s poudarkom na priseljevanju, ki je sledilo t. i. eksodusu italijanskega in delno slovenskega prebivalstva s tega območja. Procesa priseljevanja in družbene prenove sta v primerjavi z izseljevanjem do danes pritegnila le malo pozornosti zgodovinopisja in tudi drugih disciplin. Avtor oba procesa konceptualno in vsebinsko opredeli ter prikaže temeljne dinamične in strukturne poteze izseljevanja in priseljevanja, ki sta spremenila etnično in tudi družbeno podobo območja. Priseljevanje se je začelo že takoj po vojni, povečalo pa se je po zadnji fazi eksodusa sredi petdesetih let, ko je nastala prava demografska vrzel in je število prebivalstva padlo na najnižjo raven po letu 1880. Vse to, predvsem pa nove možnosti zaposlovanja, ki ga je omogočal industrijski, pristaniški in vsestranski razvoj regije, so v slovenskem republiškem in širšem jugoslovanskem državnem kontekstu pritegnile številne nove naseljence.

V obdobju Tržaškega svobodnega ozemlja so priseljenci prihajali predvsem iz notranjosti obalnega območja, delno s Tržaškega (Cona A STO) in iz Jugoslavije. Po priključitvi k Jugoslaviji se je izvorna geografija priseljevanja razširila predvsem na zahodni, a tudi preostali slovenski prostor, od Ljubljane in Celja do Maribora in Murske Sobote. Z jugoslovanskega območja je $v$ tej fazi največ priseljencev prišlo iz hrvaške Istre. Obsežno priseljevanje in ponovna demografska rast sta sovpadala z izvajanjem regionalnih razvojnih planov $v$ kontekstu socialističnega družbenogospodarskega reda. Procesa priseljevanja in družbene obnove območja nista potekala linearno in neovirano. $V$ regiji je po eni strani primanjkovalo delovne sile in vseh vrst poklicnih profilov, predvsem strokovnih in višje izobraženih kadrov, po drugi pa so na dotok priseljencev in njihovo stalno naseljevanje vplivala neskladja v razvoju infrastrukture (stanovanjska stiska) ter nekatere druge okoliščine in organizacijske težave. Avtor na koncu prispevka poudari nekatera vprašanja, ki bi bila vredna nadaljnjega preučevanja, in sicer vprašanja politike in upravljanja priseljevanja, načinov priseljevanja in adaptacije priseljencev v novem okolju ter odnosov med avtohtonim prebivalstvom ter prišleki, ki so soustvarjali novo etnično, družbeno in kulturno podobo regije. 